\section{SYNTHESIS AND ANTIBACTERIAL ACTIVITY OF NOVEL CARBAPENEMS WITH A CATECHOL OR HYDROXYPYRIDONE MOIETY}

Sir:

During the past decade the opportunistic infections, caused by various Gram-negative bacteria including Pseudomonas aeruginosa, have progressively increased and become a serious problem in chemotherapy. Recently there are many reports detailing with $\beta$-lactams containing the catechol moiety $^{1 \sim 5)}$. In addition, it has also been reported that the introduction of a mono- or dihydroxypyridone moiety ${ }^{6 \sim 12)}$ instead of a catechol group as an isostere is effective in improving stability against catechol- $O$-methyltransferase $(\mathrm{COMT})^{6}$. Such compounds show marked activity against Gramnegative organisms, in particular Pseudomonas aeruginosa. Apparently these iron-chelating groups allow $\beta$-lactams to behave as a siderophore mimic $^{13,14)}$. This characteristic enhances penetration of $\beta$-lactams through the outer membrane of Gram-negative bacteria by using siderophore transport mechanisms. However, there have been no publications on the successful attachment of catechol units to carbapenems ${ }^{15)}$. It was expected that we could create new carbapenems with a broad antimicrobial spectrum and the enhanced potency, especially against Pseudomonas aeruginosa. Here we wish to describe synthesis of these carbapenems (1, 2 and 3) and their microbial activities.
The synthetic routes employed for the title compounds are similar to those reported before $^{16,17)}$ and the typical two procedures are shown in the Scheme. First, the synthesis of compound $\mathbf{2 a}$ was performed as follows. Treatment of the enolphosphate (4) ${ }^{18)}$ with freshiy prepared mercap$\tan (5 a)$ afforded 2-substituted carbapenem ester (6a). Compound $6 \mathbf{b}$ was obtained by removal of the allyloxycarbonyl (Aoc) group in $\mathbf{6 a}$ with tetrakis(triphenylphosphine)palladium as catalyst. The introduction of the catechol-containing group could be achieved by $N$-alkylation of $\mathbf{6 b}$ with the corresponding bromide to give 7a. Hydrogenolysis of $7 \mathrm{a}$ over $10 \% \mathrm{Pd}-\mathrm{C}$ and purification by column chromatography on Diaion CHP-20P provided the desired carbapenem 2a. 2a: IR $(\mathrm{KBr}) \mathrm{cm}^{-1} 3400$ (br), 1754, 1620, 1594; ${ }^{1} \mathrm{H}$ NMR $\left(270 \mathrm{MHz}, \mathrm{D}_{2} \mathrm{O}\right)$ $\delta 1.19(3 \mathrm{H}, \mathrm{d}, J=6.9 \mathrm{~Hz}), 1.30(3 \mathrm{H}, \mathrm{d}, J=6.3 \mathrm{~Hz})$, $1.72(3 \mathrm{H}, \mathrm{m}), 2.80(1 \mathrm{H}, \mathrm{m}), 2.90(3 \mathrm{H}, \mathrm{s}), 3.01(3 \mathrm{H}$, s), $3.24(3 \mathrm{H}, \mathrm{m}), 3.40(2 \mathrm{H}, \mathrm{m}), 3.87(1 \mathrm{H}, \mathrm{m})$, $3.95 \sim 4.50(5 \mathrm{H}, \mathrm{m}), 6.91(1 \mathrm{H}, \mathrm{d}, J=8.3 \mathrm{~Hz}), 7.45$ $(1 \mathrm{H}, \mathrm{s}), 7.52(1 \mathrm{H}, \mathrm{d}, J=8.3 \mathrm{~Hz}) ; \mathrm{UV} \lambda_{\max }\left(\mathrm{H}_{2} \mathrm{O}\right) \mathrm{nm}$ 220, 263, 297.

A second synthetic route was applied to obtain the carbapenem $\mathbf{3 b}$. Treatment of $\mathbf{4}$ with mercaptan $\mathbf{5 b}$, that already had the catechol-type substituent, afforded compound $\mathbf{7 b}$. Cleavage of the allyl groups with tetrakis(triphenylphosphine)palladium, successive hydrogenolysis over $10 \% \mathrm{Pd}-\mathrm{C}$ and purification as described above provided the final product $\mathbf{3 b}$. 3b: IR (KBr) cm ${ }^{-1} 3358$ (br), 1752, 1654, 1560; ${ }^{1} \mathrm{H}$ NMR $\left(270 \mathrm{MHz}, \mathrm{D}_{2} \mathrm{O}\right) \delta 1.22(3 \mathrm{H}, \mathrm{d}, J=6.6 \mathrm{~Hz})$,

Fig. 1.
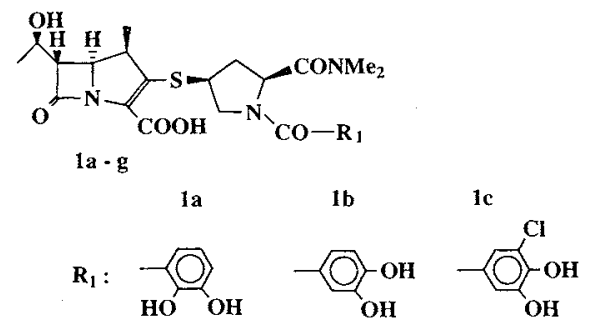<smiles>C=C1CC(O)CC1CO</smiles><smiles>Cc1ccc(O)cc1</smiles><smiles>CCc1ccc(O)c(O)c1</smiles>
$\lg$<smiles>[R]CN1CC(SC2C(C)C3C(C(=O)O)N2C(=O)[C@H]3C)CC1C(C)=O</smiles><smiles>[R]C(=O)Oc1ccc(O)c(O)c1</smiles><smiles>CCOCCNCC1CC(S[C@@H]2CN3C(=O)[C@H](C(C)O)[C@H]3C2C)CN1</smiles><smiles>Oc1cccc(O)c1</smiles><smiles>OC1CNCC2COC12</smiles><smiles>COC1CC(O)CC(O)C1O</smiles> 
Scheme 1 .

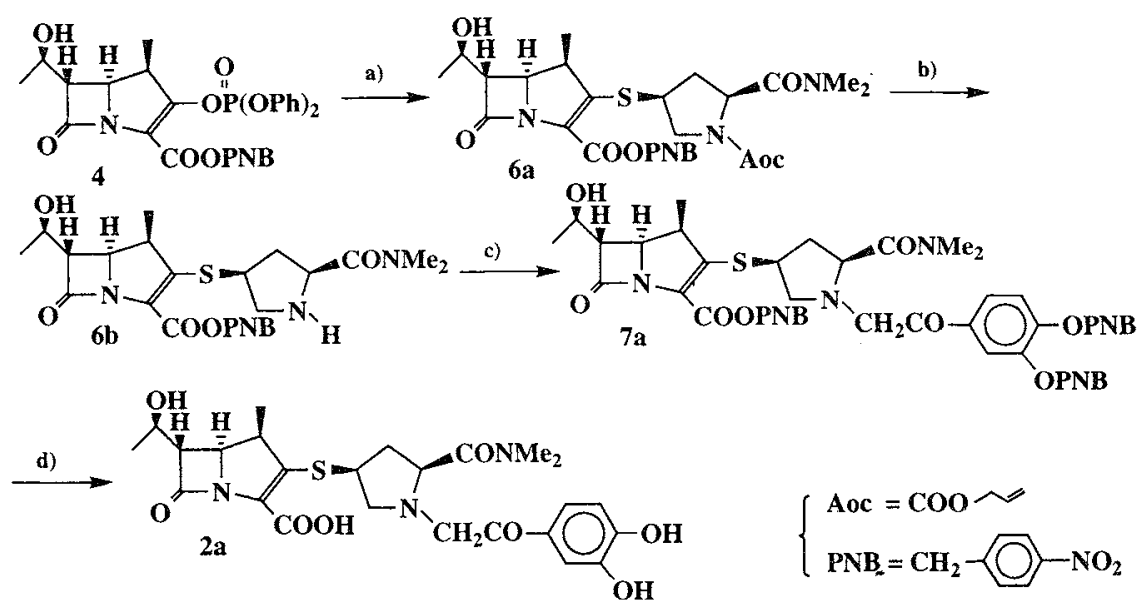

a)
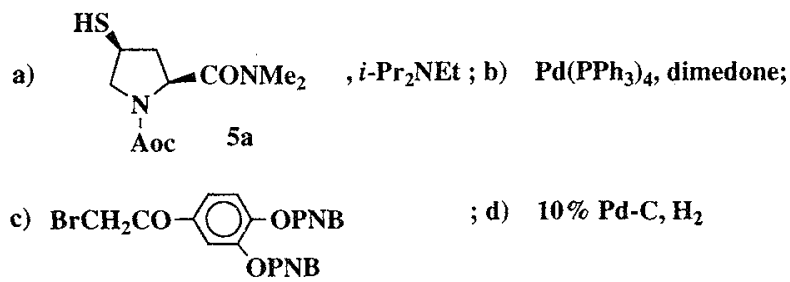

; d) $10 \% \mathrm{Pd}-\mathrm{C}, \mathrm{H}_{2}$
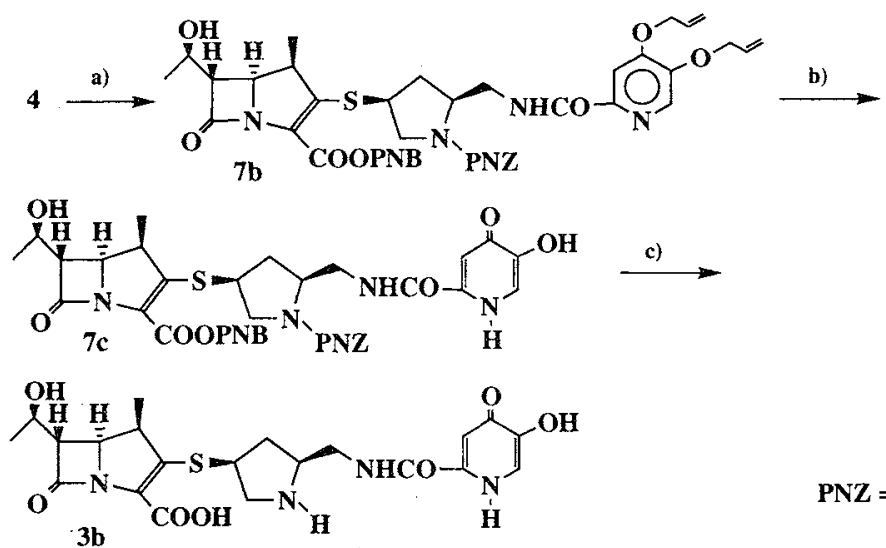

$\mathrm{PNZ}=\mathrm{COOCH}_{2}-\mathrm{NO}$

a)

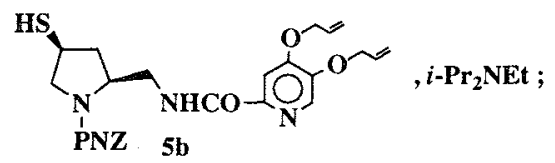

b) $\mathrm{Pd}\left(\mathrm{PPh}_{3}\right)_{4}$, dimedone; c) $10 \% \mathrm{Pd}-\mathrm{C}, \mathrm{H}_{2}$

$1.30(3 \mathrm{H}, \mathrm{d}, J=6.3 \mathrm{~Hz}), 1.78(1 \mathrm{H}, \mathrm{m}), 2.76(1 \mathrm{H}, \mathrm{m})$, $3.25 \sim 4.35(10 \mathrm{H}, \mathrm{m}), 7.12(1 \mathrm{H}, \mathrm{s}), 7.76(1 \mathrm{H}, \mathrm{s})$; UV $\lambda_{\max }\left(\mathrm{H}_{2} \mathrm{O}\right) \mathrm{nm} 295$.

The mercaptans (5) used in this work were prepared starting from trans-4-hydroxy-L-proline in similar procedures as described in the preceding papers ${ }^{16,17}$. And the catechol or hydroxypyridone fragments were synthesized according to the literature $^{1 \sim 12,19)}$.

The in vitro antibacterial activities (MIC's) of the prepared carbapenems are shown in Table $1 \sim 2$. Some of the trends with regard to the effects of structural variations on intrinsic activity can be gleaned from an examination of the MIC's for $1^{\prime}$ - $N$-substituted analogues (Table 1). All compounds $(\mathbf{1} \sim \mathbf{1 g}$ and $\mathbf{2 a} \sim 2 \mathbf{c})$ showed equal or 
Table 1. Antimicrobial activity of carbapenem compounds having the catechol-type moiety at $1^{\prime}-N$-position.

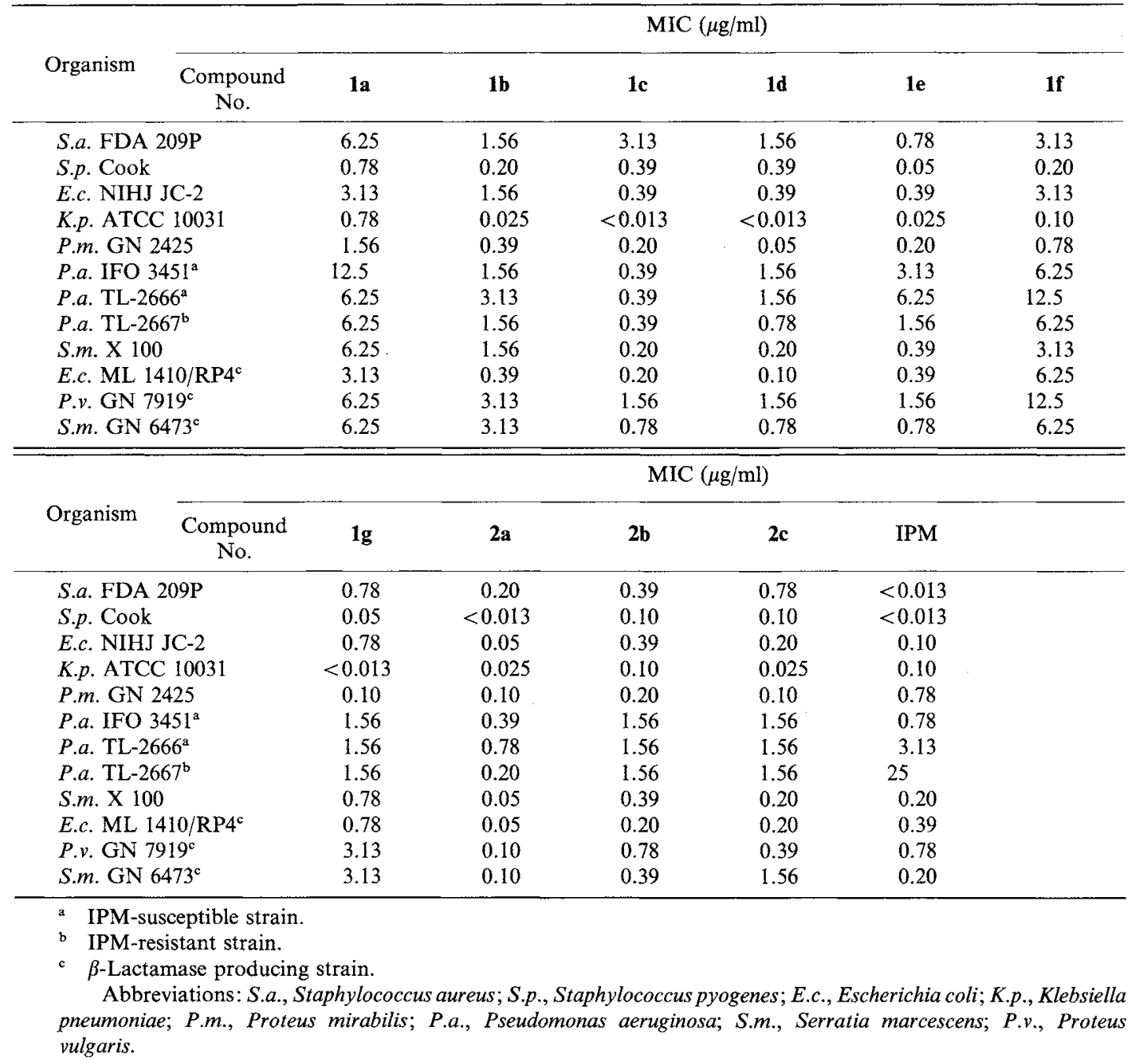

stronger antipseudomonal activity against imipenem (IPM) resistant strain (Pseudomonas aeruginosa TL-2667) compared with IPM susceptible ones (Pseudomonas aeruginosa IFO 3451 and TL-2666). This fact proves that the introduction of catechol or hydroxypyridone moiety is effective in the field of carbapenem derivatives as well as other $\beta$-lactam antibiotics. Concerning the substitution pattern in the benzene ring, a 3,4-dihydroxyphenyl group was better for the enhancement of the antimicrobial activity than a 2,3-substituted one (compare 1a with 1b). It was also observed that the introduction of the electron-withdrawing group, such as chlorine atom, in the catechol residue (compare 1b with 1c) or the utilization of the hydroxypyridone moiety instead of the catechol group (compare 1b with 1d), that might also contribute to increased stability against
Table 2. Antibacterial activity of carbapenem compounds having the catechol-type moiety at $5^{\prime}$-position.

\begin{tabular}{|c|c|c|c|c|}
\hline \multirow{2}{*}{ Organism } & \multicolumn{4}{|c|}{$\mathrm{MIC}(\mu \mathrm{g} / \mathrm{ml})$} \\
\hline & $\begin{array}{c}\text { Compound } \\
\text { No. }\end{array}$ & $\mathbf{3 a}$ & $3 \mathbf{b}$ & $3 c$ \\
\hline \multicolumn{2}{|c|}{ S.a. FDA 209P } & 0.05 & 0.05 & 0.20 \\
\hline \multicolumn{2}{|c|}{ S.p. Cook } & 0.013 & $<0.013$ & 0.025 \\
\hline \multicolumn{2}{|c|}{ E.c. NIHJ JC-2 } & 0.10 & 0.10 & 0.20 \\
\hline \multicolumn{2}{|c|}{ K.p. АТCC 10031} & 0.025 & $<0.013$ & $<0.013$ \\
\hline \multicolumn{2}{|c|}{ P.m. GN 2425} & 0.10 & 0.10 & 0.10 \\
\hline \multicolumn{2}{|c|}{ P.a. IFO $3451^{a}$} & 1.56 & 0.78 & 0.39 \\
\hline \multicolumn{2}{|c|}{ P.a. TL-2666 } & 1.56 & 1.56 & 0.20 \\
\hline \multicolumn{2}{|c|}{ P.a. TL-2667 } & 3.13 & 1.56 & 0.39 \\
\hline \multicolumn{2}{|c|}{ S.m. X 100} & 0.10 & 0.05 & 0.10 \\
\hline \multicolumn{2}{|c|}{ E.c. ML $1410 / \mathrm{RP}^{\mathrm{c}}$} & 0.20 & 0.10 & 0.20 \\
\hline \multicolumn{2}{|c|}{ P.v. GN $7919^{\mathrm{c}}$} & 0.39 & 0.20 & 0.39 \\
\hline \multicolumn{2}{|c|}{ S.m. GN $6473^{\mathrm{c}}$} & 0.39 & 0.20 & 0.39 \\
\hline
\end{tabular}

${ }^{a, b, c}$ and abbreviations: See a footnote in Table 1. 
$\mathrm{COMT}^{6,10)}$ in vivo, enhanced the potency against Gram-negative bacteria including IPM resistant $P$ seudomonas aeruginosa. The $1^{\prime}-N$-alkylated carbapenems $(\mathbf{2} \mathbf{a} \sim \mathbf{2 c})$, that had basic character, were more active than the $1^{\prime}-N$-acylated ones. The effects of the spacer length, which was considered as an important factor, was not clear on the basis of these investigations. Although the orientation of the catechol moiety could be an important factor, because the caffeic acid derivative (1g), that had more rigid conformation, showed better antipseudomonal activity than the phenylpropionic acid derivative (1f), it was estimated that the increase of acidity $\left(p K_{\mathrm{a}}\right)$ by the supplementary conjugated bonding might also affect the antibacterial activity in this case. In order to find the more appropriate position for the catechol-type substituent, 5'substituted analogues were also prepared. Among them, the derivatives $(\mathbf{3 a} \sim \mathbf{3} \mathbf{c})$, that have the iron-chelating moiety via the amidomethyl-spacer, showed enhanced antimicrobial activities against Gram-negative strains including IPM resistant Pseudomonas aeruginosa (Table 2).

In conclusion, the title compounds show the expected improvements in antimicrobial spectrum and strong activity against IPM resistant $P$ seudomonas aeruginosa. Further evaluation of $\mathbf{2}$ and $\mathbf{3}$ is in progress.

\section{Makoto Sunagawa \\ AKIRA SASAKI \\ Hiroshi Yamaga \\ Hisatoshi Shinagawa \\ Masatomo Fukasawa \\ Yoshiniro Sumita}

\begin{abstract}
Development Research Laboratories I and Discovery Research Labolatories III, Sumitomo Pharmaceuticals Research Center, 3-1-98 Kasugade-naka, Konohana-ku, Osaka 554, Japan
\end{abstract}

(Received May 27, 1994)

\section{References}

1) Breuer, H.; G. S. Bisacchi, J.-M. Drossard, P. Ermann, W. H. Koster, D. Kronenthal, P. Kuester, K. R. Lindner, H. Straub, U. D. Treuner \& R. ZAHLER: Structure-activity relationships among sulfonylaminocarbonyl activated monobactams leading to SQ-83,360. Program and abstracts of the 25th Intersci. Conf. on Antimicrob. Agents Che- mother., No. 371 , p. 158, Minneapolis, Sept. $29 \sim$ Oct. 2, 1985

2) OHI, N.; B. AoKi, T. Shinozaki, K. Moro, T. Noto, T. Nehashi, H. OKaZaKi \& I. Matsunaga: Semisynthetic $\beta$-lactam antibiotics. I. Synthesis and antibacterial activity of new ureidopenicillin derivatives having catechol moieties. J. Antibiotics 39: $230 \sim 241,1986$

3) OhI, N.; B. Aoki, K. Moro, T. Kuroki, N. Sugimura, T. Noto, T. Nehashi, M. Matsumoto, H. Okazaki \& I. Matsunaga: Semisynthetic $\beta$ lactam antibiotics. II. Effect on antibacterial activity of ureido $\mathrm{N}$-substituents in the $6-[(\mathrm{R})-2-[3-(3,4-$ dihydroxybenzoyl)-1-ureido]-2-phenylacetamido]penicillanic acids. J. Antibiotics 39: 242 250, 1986

4) Ohi, N.; B. Aokı, T. Shinozaki, K. Moro, T. Kuroki, T. Noto, T. Nehashi, M. Matsumoto, H. OKazaki \& T. Matsunaga: Semisynthetic $\beta$ lactam antibiotics. IV. Synthesis and antibacterial activity of new ureidocephalosporin and ureidocephamycin derivatives containing a catechol moiety or its acetate. Chem. Pharm. Bull. 35: 1903 1909, 1987

5) Mochizuki, H.; Y. Oikawa, H. Yamada, S. Kusakabe, T. Shinara, K. Murakami, K. Kato, J. ISHIGURo \& $\mathrm{H}$. Kosuzume: Antibacterial and pharmacokinetic properties of M14659, a new injectable semisynthetic cephalosporin. J. Antibiotics 41: 377 391, 1988

6) OHI, N.; B. Aoki, T. Kuroki, M. Matsumoto, K. KoJlMa \& T. NeHASHI: Semisynthetic $\beta$-lactam antibiotics. III. Effect on antibacterial activity and COMT-susceptibility of chlorine-introduction into the catechol nucleus of $6-[(\mathrm{R})-2-[3-(3,4-$ dihydroxybenzoyl)-1-ureido]-2-phenylacetamido]penicillanic acids. J. Antibiotics 40: 22 28, 1987

7) Mochida, K.; Y. Ono, M. Yamasaki, C. Shiraki, T. Hirata, K. SAto \& R. OKaChI: Aminothiazolylglycyl derivatives of carbacephem antibiotics. II Synthesis and antibacterial activity of novel aminothiazolyl cephem compounds with hydroxypyridone moiety. J. Antibiotics 40: 182 189, 1987

8) Weissberger, B. A.; G. K. Abruzzo, R. A. Fromtling, C. Gill, S. Ponticas, M. E. Valiant, D. L. Shungu \& H. H. Gadebusch: L-658,310, a new injectable cephalosporin. I. In vitro antibacterial properties. J. Antibiotics 42: 795 806, 1989

9) Nakagawa, S.; M. Sanada, K. Matsuda, T. Hashizume, Y. Asahi, R. Ushijima, N. Ohtake \& N. TANAKA: In vitro and in vivo antibacterial activities of BO-1341, a new antipseudomonal cephalosporin. Antimicrob. Agents Chemother. 33: $1423 \sim 1427,1989$

10) Ogino, H.; K. Iwamatsu, K. Katano, S. NakaBayashi, T. YOSHIDA, T. TSURUOKa, S. INOUye \& S. KONDO: New aminothiazolylglycylcepharosporins with a 1,5-dihydroxy-4-pyridone-2-carbonyl group I. Synthesis and biological activity of cepharosporin 
derivatives leading to MT0703. J. Antibiotics 43: $174 \sim 188,1990$

11) Ogino, H.; K. Iwamatsu, K. Katano, S. NakaBayashi, T. Yoshida, S. Shibahara, T. Tsuruoka, S. INOUYE \& S. Kondo: New aminothiazolylglycylcepharosporins with a 1,5-dihydroxy-4-pyridone2-carbonyl group II. Synthesis and antibacterial activity of MT0703 and its diastereomers. J. Antibiotics 43: $189 \sim 198,1990$

12) Maejima, T.; M. Inoue \& S. Mitsuhashi: In vitro antibacterial activity of KP-736, a new cephem antibiotics. Antimicrob. Agents Chemother. 35: $104 \sim 110,1991$

13) Miller, M. J.: Synthesis and therapeutic potential of hydroxamic acid based siderophores and analogues. Chem. Rev. 89: 1563 1579, 1989

14) Curtis, N. A. C.; R. L. Eisenstadt, S. J. East, R. J. CoRnford, L. A. WALkER \& A. J. White: Iron-regulated outer membrane proteins of Escherichia coli $\mathrm{K}-12$ and mechanism of action of catecholsubstituted cephalosporins. Antimicrob. Agents Chemother. 32: $1879 \sim 1886,1988$

15) Imuta, M; H. Itani, H. Ona, T. Konoike, S. Uyeo,
Y. Kimura, H. Miwa, S. MatsuUra \& T. Yoshida: Carbapenem and penem antibiotics. VII. Synthesis and antibacterial activity of $1 \beta$-methyl-2-(quaternary heteroaromatic-thiomethyl)carbapenems. Chem. Pharm. Bull. 39: 672 678, 1991

16) Sunagawa, M; H. Matsumura, T. Inoue, $M$. Fukasawa \& M. KaTo: A novel carbapenem antibiotic, SM-7338 Structure-activity relationships. J. Antibiotics 43: 519 532, 1990

17) Sunagawa, M.; H. Matsumura, T. Inoue, $M$. FUKASAWA \& M. KaTO: A new series of carbapenem antibiotics with $5^{\prime}$-substituted pyrrolidinylthio group at C-2 position. J. Antibiotics 44: 459 462, 1991

18) Shit, D. H.; F. Baker, L. Cama \& B. G. CHRISTENSEN: Synthetic carbapenem antibiotics $I$. 1- $\beta$-Methylcarbapenem. Heterocycles 21: $29 \sim 40$, 1984

19) Bedeschi, A.; G. Visentin, E. Perrone, F. Giudici, F. Zarini, G. Franceschi, G. Meinard, P. Castellani, D. Jabes, R. Rossi \& C. D. Bruna: Synthesis and structure-activity relations in the class of 2-(pyridyl)penems. J. Antibiotics 43: 306 313, 1990 